\title{
Squamous Cell Carcinoma of the Pancreas
}

\author{
Pierlesky Elion Ossibi ${ }^{*}$, Issam Yazough1, Amal Bennani'2, KarimIbn Majdoub1, \\ Imane Toughrai ${ }^{1}$, Said Ait Laalim¹, Abdelmalek Ousadden'1, Laila Chbani², Khalid Mazaz' \\ Khalid Ait Taleb ${ }^{1}$ \\ ${ }^{1}$ Visceral Surgery Department, Hassan II University Hospital, Fez, Morocco \\ ${ }^{2}$ Anatomy and Pathological Cytology Department, Hassan II University Hospital, Fez, Morocco \\ Email: $\underline{\text { oselion@yahoo.fr }}$
}

Received 25 August 2014; revised 20 September 2014; accepted 15 October 2014

Copyright (C) 2014 by authors and Scientific Research Publishing Inc.

This work is licensed under the Creative Commons Attribution International License (CC BY). http://creativecommons.org/licenses/by/4.0/

(c) (i) Open Access

\begin{abstract}
Exocrine pancreatic tumors are dominated by adenocarcinomas that have a poor prognosis. Squamous Cell Carcinoma of the pancreas is rare. We report a case of squamous cell carcinoma of the pancreas in a 75-year-old patient admitted to the emergency ward with acute cholangitis.
\end{abstract}

\section{Keywords}

\section{Carcinoma, Squamous Cell, Pancreas}

\section{Introduction}

Exocrine pancreatic tumors are dominated in terms of frequency by adenocarcinomas that are malignant tumors whose prognosis is more severe. However, rare forms of malignant tumors of the pancreas exist including squamous cell carcinoma of the pancreas. Thus, we report the case of a 75-year-old patient with no notable history, presented with cholangitis. Subsequent imaging showed a tumor in the head of the pancreas for which histological examination confirmed squamous cell carcinoma of the pancreas.

\section{Case Report}

A 75-year-old patient non smoker with one month history of right upper quadrant pain with obstructive jaundice, fever and deterioration of general status.

On physical examination, patient was visibly ill with jaundice, $39^{\circ} \mathrm{C}$ fever and right upper quadrant tenderness. Laboratory tests showed cholestasis, leukocytosis and elevated CRP with normal kidney function.

Abdominal ultrasound revealed bile ducts dilation with common bile duct $15 \mathrm{~mm}$, upstream of a hyper echo-

\footnotetext{
${ }^{*}$ Corresponding author.
}

How to cite this paper: Ossibi, P.E., Yazough, I., Bennani, A., Majdoub, K., Toughrai, I., Laalim, S.A., Ousadden, A., Chbani, L., Mazaz, K. and Taleb, K.A. (2014) Squamous Cell Carcinoma of the Pancreas. Surgical Science, 5, 487-489. 
genic heterogeneous lesion of the pancreatic head taking the Doppler and measuring $8.7 \times 8.4 \mathrm{~cm}$.

A CT scan showed intra hepatic bile duct dilation with common bile duct dilation at $17 \mathrm{~mm}$ upstream of a process of the head of pancreas with peri pancreatic nodular carcinomatosis (Figure 1).

The patient was placed under broad spectrum antibiotics followed by emergency endoscopic biliary drainage A CT guided pancreatic punction-biopsy was performed with the histology showing poorly differentiated invasive squamous cell carcinoma of the pancreas (Figure 2).

The case was discussed in a multidisciplinary meeting where palliative chemotherapy was decided. Patient was referred to Oncology for chemotherapy.

\section{Discussion}

Squamous cell carcinoma of the pancreas is very rare.

Eight cases of squamous cell carcinoma Pancreatic have been reported in the literature since 1990 [1]-[3]. In the classification of tumors outlined by WHO [4], squamous cell carcinoma falls under adenosquamous tumor. The histogenesis of pancreatic squamous cell carcinoma is unclear. Two hypotheses have been proposed to explain this: the degeneration of squamous metaplasia of the ductal epithelium and the transformation of a tumor whose adenosquamous adenocarcinoma component would have completely disappeared [1]. The canal squamous metaplasia is common. It was observed in $48 \%$ of cases of an autopsy series of 83 American veterans [5] and in $21 \%$ of cases in a series of 73 biopsies from patients with chronic pancreatitis [6].

Pancreatic carcinoma adenosquamous type is a known histological form. Its incidence ranges from $0.4 \%$ to

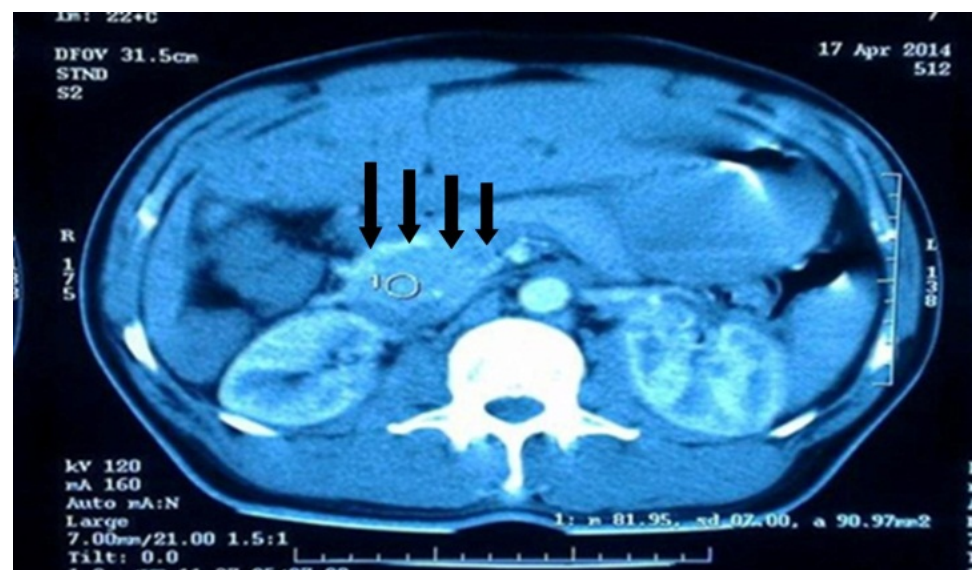

Figure 1. Abdominal CT scan showing tumor of the pancreatic head.

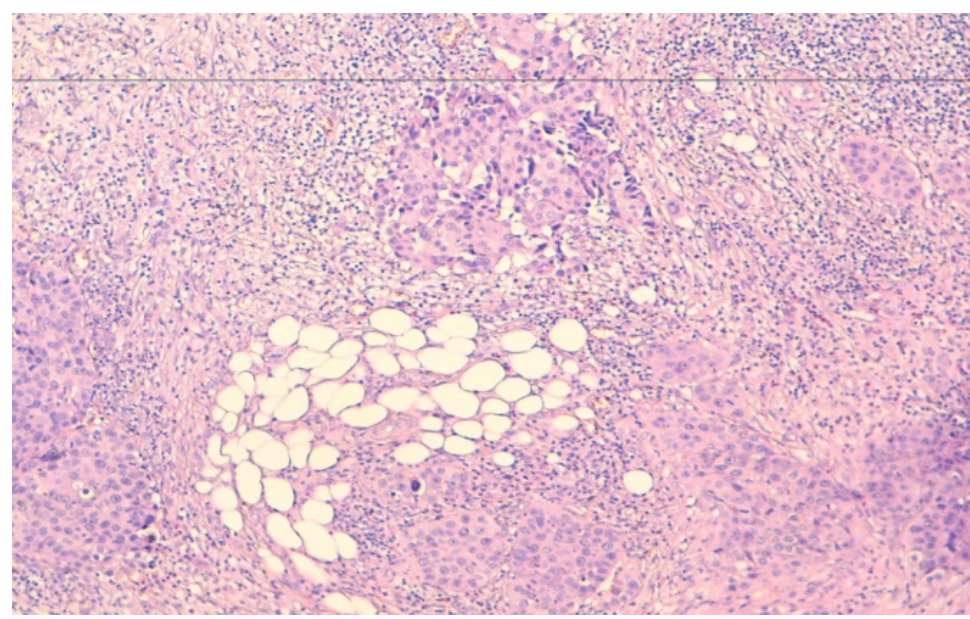

Figure 2. Poorly differentiated proliferation in pools and in clumps with high expression of CK 5/6; $(\mathrm{HES} \times 10)$. 
$4.2 \%$ depending on the study [2]. It is characterized by the presence of varying proportions of two tumors contingents: squamous and glandular. For a tumor to be considered adenosquamous, the squamous component must represent more than $30 \%$ of the tumor [4].

In CT scan, there is often a peripheral contrast in the lesion after injection of contrast [7].

These tumors, often voluminous, have grim prognosis at diagnosis, with loco regional and lymph nodeinvasion very common [8], as well as metastases, which were reported in six other cases in the literature [3] [9] [10]. Baylor et al. reported a 5-year survivalrate of less than 1\% [11], Beyer et al. a 1-year survival of 4.8\% [2]. Median survival is 2 months [10].

The therapeutic treatment of squamous cell carcinoma is the same as that of all adenocarcinomas. However, loco regional andmetastastic invasionvery common, makes most tumors unressectable. Patients who undergo a curative or palliative treatment (dual or single biliodigestive bypass) surgery have a better prognosis [3]. In case of unresectable or metastatic tumor, radiation or a combination chemotherapy radiation did not prove effective [10]. Systemic chemotherapy has rarely been effective.

In our case, the particularity being highlighted here, not only being especially the histological type, but also the presence of peritoneal carcinomatosis hence our decision to perform a pancreatic punction-biopsy in order to confirm the aforementioned histological nature and commence subsequent treatment.

\section{Conclusion}

Squamous cell carcinoma of the pancreas is a rare tumor. Apart from some specific morphological characteristics, its clinical presentation is the same as that of adenocarcinoma. Curative or palliative surgical treatment should be performed when tumor extension and patient's general condition permit. If not, the use of chemotherapy can lead to an improvement of the general condition.

\section{References}

[1] Bralet, M.P., Terris, B., Bregeaud, L., Ruszniewski, P., Bernades, P., Belghiti, J., et al. (1999) Squamous Cell Carcinoma and Lipomatous Pseudo-Hypertrophy of the Pancreas. Virchows Archiv, 434, 569-572. http://dx.doi.org/10.1007/s004280050385

[2] Beyer, K.L., Marshall, J.B., Metzler, M.H., Poulter, J.S., Seger, R.M. and Diaz-Arias, A.A. (1992) Squamous Cell Carcinoma of the Pancreas. Report of an Unusual Case and Review of the Literature. Digestive Diseases and Sciences, 37, 312-318. http://dx.doi.org/10.1007/BF01308190

[3] Da Fonseca, J., Brito, M.J., Castro, C., Lopes, L., Folgado, A., Murinello, F., et al. (2000) Pancreatic Squamous Carcinoma Mimicking a Bleeding Duodenal Ulcer. Gastrointestinal Endoscopy, 51, 362-363. http://dx.doi.org/10.1016/S0016-5107(00)70374-9

[4] Klöppel, G., Hruban, R.H., Longnecker, D.S., Adler, G. and Kern, S.E. (2000) Ductal Adenocarcinoma of the Pancreas. In: Hamilton, S.R. and Aaltonen, L.A., Eds., Pathology and Genetics of the Digestive System (World Health Organization Classification of Tumours), IARC Press, Lyon, 221-229.

[5] Pour, P.M., Sayed, S. and Sayed, G. (1982) Hyperplastic, Preneoplastic and Neoplastic Lesions Found in 83 Human Pancreases. American Journal of Clinical Pathology, 77, 137-152.

[6] Cylwik, B., Nowak, H.F., Puchalski, Z. and Barczyk, J. (1998) Epithelial Anomalies in Chronic Pancreatitis as a Risk Factor of Pancreatic Cancer. Hepato-Gastroenterology, 45, 528-532.

[7] Koduri, V.G. and Ravi, T.J. (1994) Squamous-Cell Carcinoma of the Pancreas: Report of a Case and Review of ERCP Findings. Endoscopy, 26, 333-334. http://dx.doi.org/10.1055/s-2007-1008985

[8] Serafini, F., Rosemurgy, A.S. and Carey, L.C. (1996) Squamous Cell Carcinoma of the Pancreas. The American Journal of Gastroenterology, 91, 2621-2622.

[9] Colarian, J., Fowler, D., Schor, J. and Poolos, S. (2000) Squamous Cell Carcinoma of the Pancreas with Cystic Degeneration. Southern Medical Journal, 93, 821-822. http://dx.doi.org/10.1097/00007611-200093080-00019

[10] Itani, K.M., Karni, A. and Green, L. (1999) Squamous Cell Carcinoma of the Pancreas. Journal of Gastrointestinal Surgery, 3, 512-515. http://dx.doi.org/10.1016/S1091-255X(99)80105-X

[11] Baylor, S.M. and Berg, J.W. (1973) Cross-Classification and Survival Characteristics of 5,000 Cases of Cancer of the Pancreas. Journal of Surgical Oncology, 5, 335-358. http://dx.doi.org/10.1002/jso.2930050410 
Scientific Research Publishing (SCIRP) is one of the largest Open Access journal publishers. It is currently publishing more than 200 open access, online, peer-reviewed journals covering a wide range of academic disciplines. SCIRP serves the worldwide academic communities and contributes to the progress and application of science with its publication.

Other selected journals from SCIRP are listed as below. Submit your manuscript to us via either submit@scirp.org or Online Submission Portal.
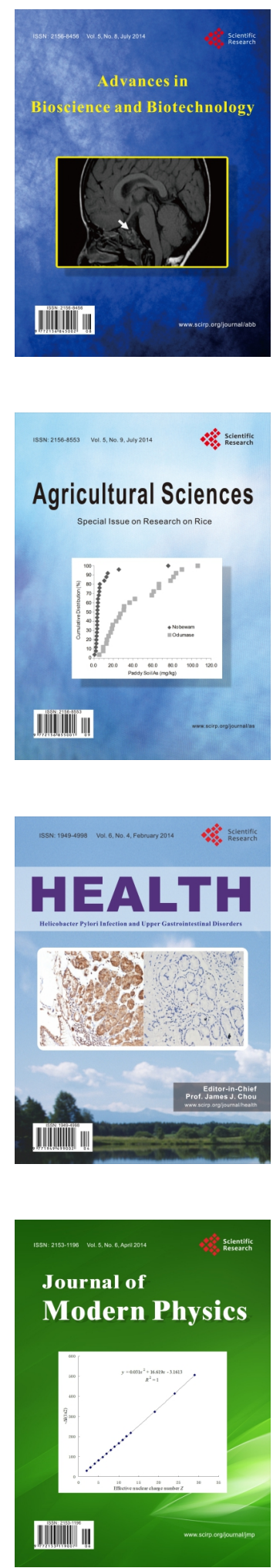
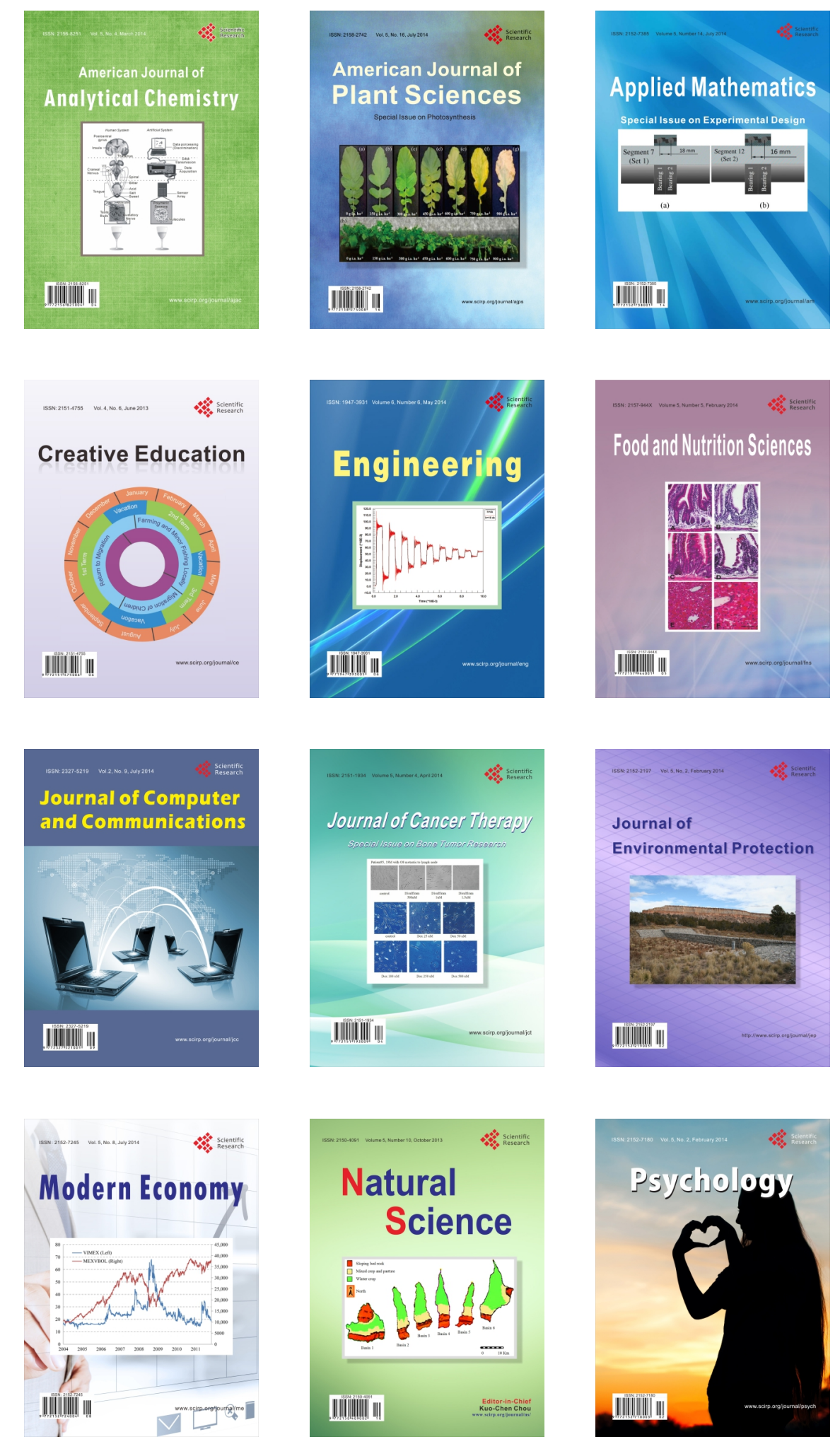